Sarah Carpenter, Pamela M. King, Meg Twycross, and Greg Walker, eds. 'The Best Pairt of our Play': Essays Presented to John J. McGavin. Medieval English Theatre, 38. Cambridge, D.S. Brewer, 2017. Pp 183. Paperback £25.00. ISBN: 9781843844518 .

\title{
SHEILA CHRISTIE
}

Cape Breton University

As a colleague and mentor, John J. McGavin has had a profound impact on medieval drama studies. His interest in broadly defined performance, including ritual and ceremony; his detailed exploration of archival material in both England and Scotland; and his attention to spectatorship are all evident in the work of his students and peers in this second volume of Medieval English Theatre's Festschrift dedicated to him. The volume progresses from articles focusing on archival studies to those more concerned with audience and spectatorship. McGavin's attention to medieval performance outside of England influences the first four articles in the collection, which address material related to Scotland and Wales. Most of the other contributions address spectatorship more directly, leading the volume into discussions of direct address, performance circumstances, and more theoretical discussions around audience reception. The volume ends with a detailed analysis of a little studied sixteenth-century play, leaving the reader aware that there is still much to discover by following McGavin's interests and methods.

Eila Williamson, who first worked with McGavin as a research assistant, begins the volume with an excellent exploration of the Scottish Buccleuch family's records in order to provide a fuller account of the first Earl of Buccleuch's heraldic funeral in 1634. Williamson's thorough consideration of extant records significantly augments a seventeenth-century heraldic account, giving a fuller picture of the extent of funeral activities, including cost, personnel, and visual and aural presentation. She demonstrates the attention to detail that made this funeral a carefully orchestrated performance lasting for months, from formal displays in London and Leith to the eventual procession to the family home and vault. Williamson's discussion of the contemporary elegiac and dramatic references that make Buccleuch a figure of literary interest feels tacked on to the end of the article, but these references do serve to demonstrate the broader appeal of her subject. Alice Hunt's article moves the Scottish focus southwards, showing how James I's English coronation and contemporary commentary on the ceremony privileged performance over performativity; instead of a divine transformation, contemporaries understood the modified ceremony as 'symbolic gestures in [the] drama of kingship' (32). Sue 
Niebrzydowski and David N. Klausner move the volume's attention to Wales, respectively exploring the Welsh language Troelus a Chresyd and a possible Crucifixion play in early fourteenth-century Monmouthshire. Niebrzydowski provides a thorough introduction to the Welsh adaptation of the Troilus and Criseyde story, showing how the text amalgamates aspects of Chaucer's and Henryson's retellings. She dates the text to the turn of the seventeenth century, a time of theatrical interest in the story in London, but she notes that Troelus a Chresyd differs in narrative from other theatrical adaptations. Instead, the Welsh text's anonymous author most likely modeled his work on Thomas Speght's edition of Chaucer, which misattributes Henryson's version to Chaucer. Niebrzydowski's argument about Speght as the intermediary source is more difficult to follow and is not always convincing, in part because she is comparing Middle English and Scots to Welsh, but also because she does not clearly demonstrate the point she wants her readers to understand in her comparisons between texts. Her overall discussion of the play, nevertheless, provides a useful starting point for scholars interested in Welsh drama or the Troilus and Criseyde tradition. Klausner's discussion focuses on an archival allusion to performance in Bishop Orleton's letter outlining abuses identified during his visitation of the Benedictine Priory of St Mary at Abergavenny, Monmouthshire in 1320. Klausner expertly demonstrates the filters through which he interprets this allusion, and he draws on the practices of contemporary liturgical drama to suggest that Orleton's letter describes a Crucifixion play or tableau, possibly one that received regular performance. $\mathrm{He}$ concludes the article with a brief consideration of a reference to parish drama in fifteenth-century Abergavenny, suggesting that the two references to performance in the same place two centuries apart may be all that remains of a local dramatic tradition in a region where records generally do not survive.

Elisabeth Dutton marks the volume's shift towards spectatorship with her discussion of how both visual and dramatic arts use parodic and metatheatrical techniques to foreground ideal spectatorship. Comparing how spectatorship figures in both a painting of the Annunciation and a 1602 St John's College, Oxford play of Narcissus, Dutton playfully elucidates the ways in which a viewer or audience's awareness of their own spectatorship provides the aesthetic distance necessary for audiences to benefit from the material. In her contribution on authority and audience address, Charlotte Steenbrugge tackles a commonplace association between sermons and morality plays, showing how the rhetorical tactics and speaker-audience relationships implicit in each differ from one another. Steenbrugge usefully demonstrates the fragile authority that dramatic performers have in relation to their audiences, and consequently the ways in which plays make audiences work 
to extract virtuous messages in contrast to the more assertive didacticism of sermons with their assumed position of authority over their auditors.

Nadia Thérèse van Pelt and Mishtooni Bose respectively present the most theoretically grounded articles of the collection, with van Pelt addressing the 'Cognitive Turn' in medieval drama scholarship and Bose exploring how medieval dialogue can invoke the 'Theatre of the Mind'. Because van Pelt's goal is to navigate between metatheatrical and cognitive approaches to spectatorship, much of the article explains how these theories articulate the audience's relationship between reality and artifice, including the balance of immersive experience and intellectual engagement. Towards the end, van Pelt briefly discusses the dynamics of risk, showing how some medieval performances carefully navigated the boundaries of reality and artifice in order to be effective. While it would be helpful to see the author develop these ideas around risk and historically situated spectators further, the article serves as a useful companion to Dutton's and Steenbrugge's contributions, as well as to Pamela M. King's, discussed below. van Pelt's contribution also represents the increasing importance of interdisciplinary, theoretical work on spectatorship. Like van Pelt, Mishtooni Bose is interested in risk, although her focus is on dialogues (textual and theatrical) that allow for the 'possibility of a true meeting between self and Other', as evidenced by dialogic impasse or aporia (122). Both Bose's theoretical perspective and her broad range of textual examples (including in-depth considerations of The Lyfe of Soule, Lucidus and Dubius, and Wisdom) make this contribution a more difficult read. Nonetheless, she draws an important distinction between dialogues which limit conflict and those which allow openness and doubt, with the latter serving as a performance of thought that models the possibility of co-created knowledge.

Pamela M. King returns the volume's focus to material experience in her article on the aural contexts of medieval English outdoor performance. King challenges scholars' tendency to privilege visual analysis of performances and plays, exploring ways in which sound is significant within scripts, performances, and contemporary soundscapes. The article is wide-ranging in its considerations of sound, mimicking the complexity of the aural fabric it describes, but it ultimately urges scholars to consider how sound influences spectators on a 'perceptual level which precedes the cognitive' and is 'fundamentally constitutive of performance space' $(134,141)$. Returning to an archival focus, Clare Egan provides a convincing articulation of female involvement in early modern libel practices. Starting from an understanding of libel as a performance that intentionally set out to achieve specific effects with identifiable audiences, Egan demonstrates how women participated as instigators, managers, and auditors, encouraging the circulation of 
libel, despite their seemingly limited presence in libel records. David Mills posthumously concludes the volume with a lovely exploration of the play Abraham Sacrifiant. Mills shows how this play (translated into English in 1575 by the Puritan Arthur Golding, and initially composed in French in 1550 by Théodore de Bèze) uses a plain style, emotionally affective dialogue, and ambiguity to present flawed, human characters who each take a different approach to faith.

This wide-ranging volume, overall, has several entertaining and useful contributions. The volume represents McGavin's influence well, reflecting his attention to material outside of England, as well as his excellent work in archival studies and spectatorship. Contributions from both his students and his peers reflect the high esteem he has earned in the field of medieval drama studies. The volume provides insight into archival and theoretical questions, drawing attention to often overlooked material and performance implications. By ending with a close, critical analysis, the volume also reminds us that under all the archives and theories that stimulate our curiosity lie the texts that delighted both medieval audiences and modern scholars, drawing us back, once again, into the treasures of the past. 